\title{
Performance Analysis of a Hypothetical 1-Hectare PV Plant in the Benguela Region. The First Year of Operation
}

\author{
Luís Filipe Ramos ${ }^{\mathrm{a}}$, Zenaida Mourão ${ }^{\mathrm{b}}$ and Carlos Pinho ${ }^{\mathrm{c}}$
}

${ }^{a}$ DEMEC, Faculdade de Engenharia, Universidade do Porto, Rua Dr. Roberto Frias, s/n, Porto, Portugal.

'INEGI, Campus da FEUP, Rua Dr. Roberto Frias, 400, Porto, Portugal.

'CEFT, DEMEC, Faculdade de Engenharia, Universidade do Porto, Rua Dr. Roberto Frias, s/n, Porto, Portugal.

\section{ARTICLE INFO}

\section{Keywords:}

Solar energy,

photovoltaic

panels,

energy

efficiency,

exergy

efficiency.
The present study evaluates the performance of a hypothetical 1-hectare solar photovoltaic (PV) plant located in the Baía Azul Beach, in Benguela, Angola. The first year performance of the plant composed by 2,784 DuoMax 365 PV modules from Trina Solar Company was evaluated by means of the VelaSolaris Polysum software package. The total surface area of the PV modules was of $5,456.64 \mathrm{~m}^{2}$. The annual alternate current electricity production was of $1,511.70 \mathrm{MWh}$ allowing a total of $710.47 \mathrm{t}_{\mathrm{CO} 2}$ of $\mathrm{CO}_{2}$ emissions reduction and a performance ratio of $72.8 \%$. The annual average energy and exergy efficiencies of the PV system were respectively of $14.3 \%$ and $14.7 \%$.

\section{Introduction}

The solar photovoltaic (PV) industry is one of the fast growing industries in the world and in 2018 it had worldwide installed power of $505 \mathrm{GW}^{[1]}$ Solar photovoltaic systems can speed up the decentralization of energy production and distribution, improving the local creation of jobs and subsequent economic growth. They can guarantee the absence of negative environmental impacts, namely carbon dioxide emissions ${ }^{[2]}$. To keep up with this high grow rate on the spread of the PV application, new technologies have been developed, either in terms of the consumed energy in the fabrication of the PV modules as well as in new operating concepts in order to increase the PV cells efficiency ${ }^{[3]}$.

The incident solar radiation in Angolan is high and almost constant along the year, and there is a positive convergence of several factors, the high incident solar radiation, the low ambient temperature variation, the low wind velocity in coastal regions and a large availability of free land for the installation of large-scale PV systems. The country has an average yearly number of sun hours in the 3600 to 5800 range $^{[4]}$

Angola is one of the major oil producers of the African continent, but its electricity is mainly available through hydroelectric plants ${ }^{[5]}$. To widen the renewable energy share on the electricity production, the Angolan Ministry of Water and Energy wishes that until 2025 there will be a 4.5 fold increase on the electrical energy generation capacity ${ }^{[6]}$. Besides, there is also the need for private sectorial activities as well as political and social stability in order to invest in the renewable energy sources ${ }^{[7]}$ The approval of the Decreto Presidencial N. 256/11 from the $29^{\text {th }}$ November of the National Energy Politic and Strategy (Política e a Estratégia de Segurança Energética Nacional) defines the required strategic orientations for the energy sector in order to guarantee regular, qualified and competitive costs for business enterprises and population in general.

In Angola, the majority of companies and many households have their own diesel electricity generators, and consequently Angola is the world number one importer of diesel generators ${ }^{[8]}$. In less demanding situations, where the energy storage is not an obligation, the solar nonbattery PV systems can reduce the diesel dependency at low cost, by operating as a complement to these fossil fuel generators ${ }^{[9]}$. The increasing demand of electricity to power air conditioning and ventilation systems, either domestic or industrial, has a huge impact on the use of diesel electricity generators. This equipment, besides the environmental burden due to the emission of combustion exhaust gases added to a noisy environment, negatively influences the population health ${ }^{[8]}$. The generation of the electricity through renewable energy sources, would thus have a twin effect upon the society, as it not only could reduce the above-mentioned environmental impacts, but also the country dependence on fossil fuels. The PV electricity production systems have the shortest (in less than one year) installation period, combined with the lowest maintenance costs.

The PV technology still faces some barriers to its development, such as difficulties to find out proper financing schemes, financial or economic unstable situation or bad quality of equipment proposed by the dealers due low market transparency, as it happens in many African countries. Also high prices or taxes imposed on such equipment, lead to difficult conditions for many communities and keep fossil fuels as reference in the energy production sector in several third world countries. In other words, the PV development depends on the competitiveness of other energy production technologies ${ }^{[10]}$.

In the Benguela region, only $59 \%$ of its population has access to potable water, the water mains system did not keep the pace with the population growth. In 2017, only $43 \%$ of the population had access to an irregular and faulty electricity distribution network ${ }^{[1]}$. The improvement of the electricity distribution services is of paramount importance for the Angolan development as well as easy access to potable water. 


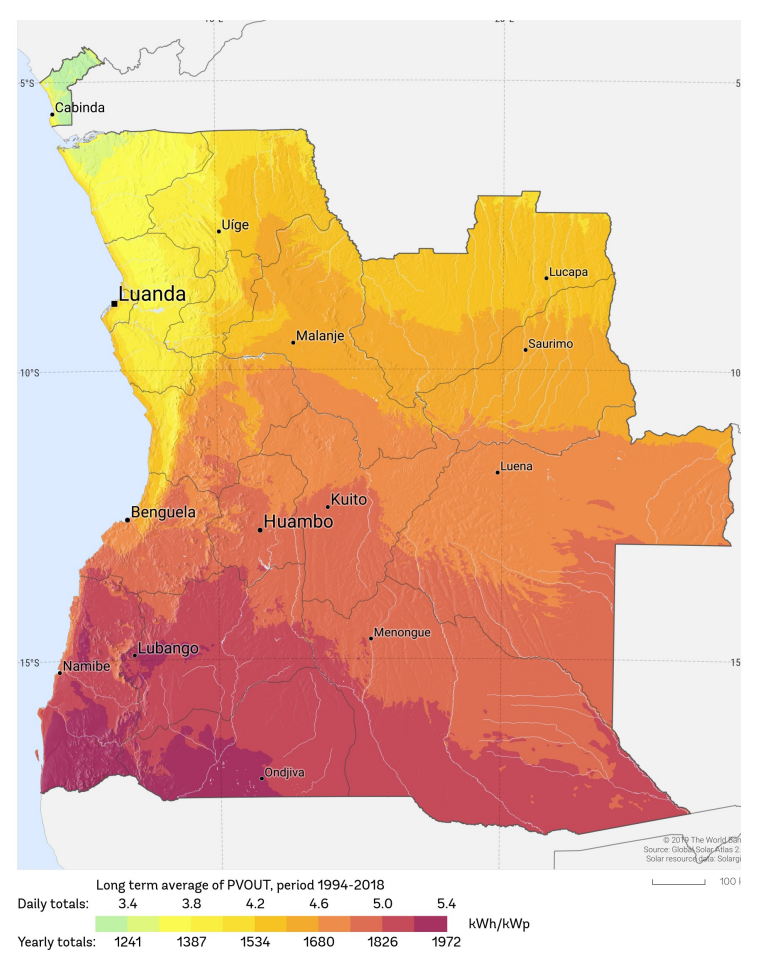

Figure 1. PV potential of Angola ${ }^{[11]}$.

Figure 1 shows the PV potential of Angola and in it, there is a relationship between the expected yearly energy (electricity) [kWh] production with the installed power output [kWp]. Due to its high potential, the Benguela province is well placed in terms of the capabilities for the implementation of PV systems.

The Benguela region has all the requirements for the installation of a PV central. There are many available locations, with flat unoccupied land and consequently the shading effects are inexistent or negligible. The choice was for a $10,000 \mathrm{~m}^{2}$ overall plant area to be coherent with a previous study concerning a solar pound also in the same region ${ }^{[13]}$, and the possible localization was in Baía Azul south of Benguela city. It is close to the Atlantic Ocean, with plain flat terrain, has the influence of sea breezes that might promote the self-cleaning action of the PV panels and is easily accessed, Figure 2. This region has a high touristic and fishing activity and consequently has close by costumers for the produced electricity. The present analysis, part of a more general study ${ }^{[12]}$, evaluates the performance of a hypothetical PV system installed in a $10,000 \mathrm{~m}^{2}$ area for electricity production in the Benguela region.

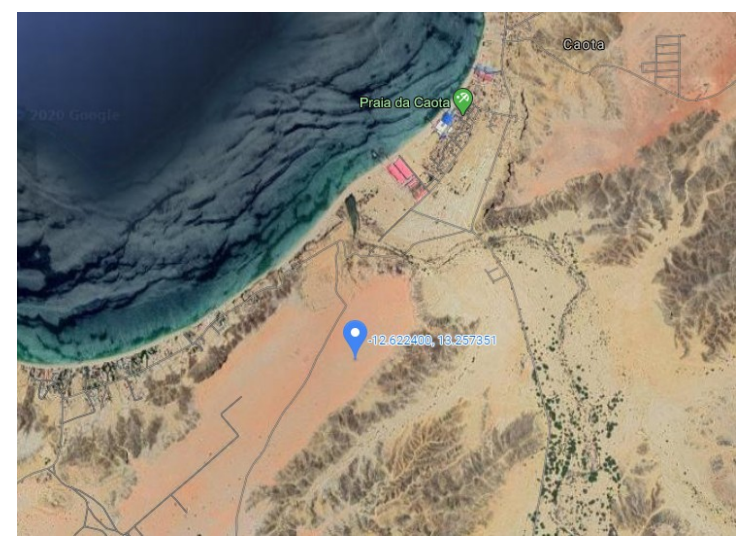

Figure 2. Location of the studied PV system ${ }^{[14]}$.

\section{Methodology}

\subsection{Evaluation of the Solar Resource}

The VelaSolaris Polysum software package ${ }^{[15]}$ was used to obtain the climatic data for this region, taking into account its geographic coordinates:

\author{
i. Latitude $\varphi, 12.62$ o South; \\ ii. Longitude $\lambda, 13.25$ East; \\ iii. High above sea level, $10 \mathrm{~m}$.
}

The result of such analysis is in Figure 3 below, and an important conclusion is that Benguela has a reasonable ambient average temperature.

In this Figure 3, in red, there is the monthly temperature variation, and the thicker bars refer to the standard deviation, thus extreme temperatures are rare, which is a good operating argument for the performance of the PV system. In green and in blue, and referred to the secondary ordinate axis, are plotted the relative humidity and the rainfall. These climatic data are from the average hourly values obtained in the 2000 to 2009 period $^{[15]}$.

The electrical current produced by the PV panels is of the direct current (DC) type, and before sending to the electricity network it must be converted into alternate current (AC) in the inverters. The PV cells and the electrical current inverters, composing a solar PV plant, undergo a performance decrease with the operating temperature increase and warmer months are highly armful for the electricity production. The relative humidity values, rarely above $80 \%$, Figure 3, are another advantage minimizing thermal discomfort. As far as rainfall is concerned, the period of stronger precipitation is about three months, between January and April. According to V'asquez et al. ${ }^{[16]}$ the climatic classification of the region is Bsh, which means a semiarid warm climate, with high summer temperatures, slightly lower ones in winter and short well defined rainy seasons.

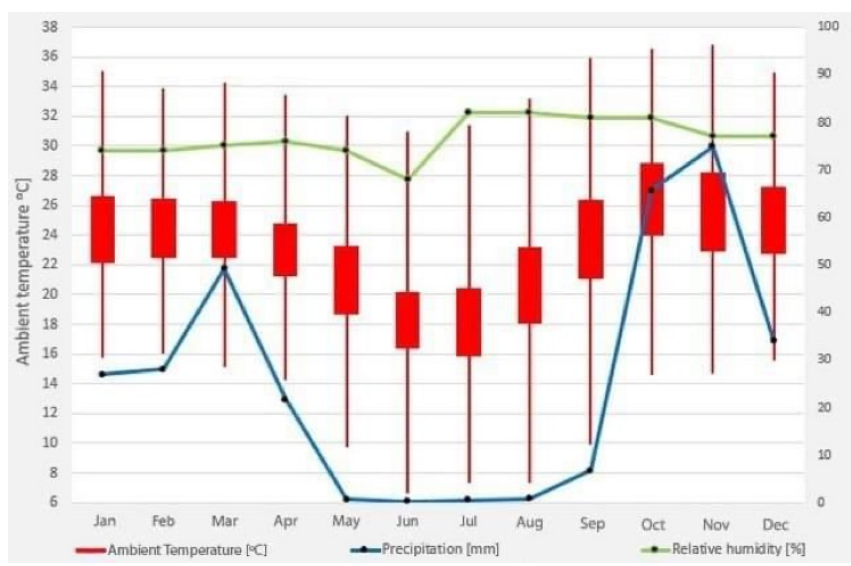

Figure 3. Variation of ambient temperature, rainfall and relative humidity, for the Benguela region ${ }^{[15]}$.

Concerning the solar radiation levels, the region has high solar indexes showing a small reduction between June and September. To find out the electrical energy produced, the Polysum software gives the direct radiation in a horizontal plane, the diffuse and the global radiation in the inclined module surface, Figure 4 , and the obtained annual incident radiation in the module plane is $2.038 \mathrm{kWh} / \mathrm{m}^{2}$. Those two indexes demand the knowledge of the inclination angle of the module with the horizontal ${ }^{[15]}$. The definition of the Sun/Earth interaction is dependent upon a set of parameters defining the relative position between the Sun and the Earth. The solar declination $\delta s$ is the angle between the Sun/Earth imaginary connecting line and the equator plan. The solar hour angle $\omega$ is the angle between the meridional location plane and the hour cycle. The solar height $\alpha s$ is the angle between the Sun direction and the local horizontal plane. Finally, the azimuth $\gamma s$ is the angle between the South direction and the horizontal projection of the Sun/Earth line ${ }^{[17]}$.

The daily period duration in hours, i.e., the number of daily sun hours between sun rise and sun set, $D$, the two time instants when the solar high $\alpha s$ is zero ${ }^{[17]}$, is determined by means of Eq. 1 and in Figure 4 the red line represents the variation of this day time duration along one year. 
$D=\frac{2}{15} \cos ^{-1}\left(-\tan \phi \tan \delta_{s}\right)$

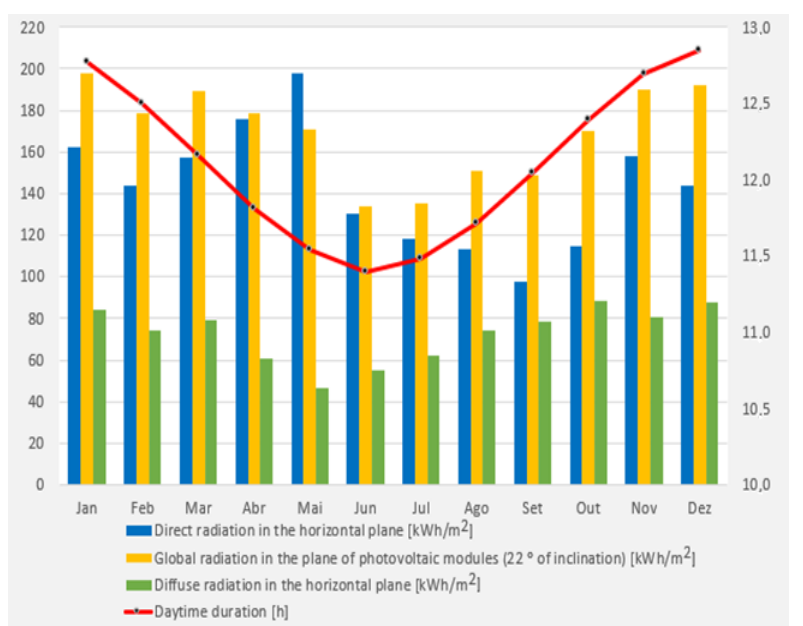

Figure 4. Yearly evolution of the different radiation levels and daytime duration ${ }^{[15]}$.

\subsection{Configuration of the PV System}

Because the PV system is by the sea, the panels or modules must be rough enough to withstand either marine corrosion or occasional strong winds. The Trina Solar modules were chosen as these are built with anticorrosion materials and double glazing ${ }^{[18]}$. To maximize the electricity production, the choice was for the DuoMax 365 PV module with the highest peak power. It is composed by 72 monocrystalline cells allow high efficiency and its main characteristics are presented in Table 1.

The inverters disposition will be in rows as with this configuration there are no shading effects. A different layout would create shaded areas reducing the produced electricity current. The individual adaptation of the maximum power operating point for each array increases the system efficiency. As all modules operate with same current, in case of shaded cells the maximum total array power operating point would be reduced, instead of going to the value obtained for non-shaded conditions. Besides these shaded power losses, because of less incident energy targeting the shaded modules, there are still incompatibility losses and in the case of a malfunctioning array, the other rows will operate properly, delivering the produced electricity.

\begin{tabular}{|c|c|}
\hline Characteristic & Value \\
\hline Peak power & $365 \mathrm{~W}$ \\
\hline Open circuit tension, $V O C$ & $47.3 \mathrm{~V}$ \\
\hline Short circuit current, ISC & $9.88 \mathrm{~A}$ \\
\hline Tension at maximum power, $V M P P$ & $39.1 \mathrm{~V}$ \\
\hline Current at maximum power, IMP P & $9.35 \mathrm{~V}$ \\
\hline Module surface area & $1.96 \mathrm{~m}^{2}$ \\
\hline Maximum acceptable temperature & $70 \stackrel{\circ}{C}$ \\
\hline Minimum acceptable temperature & $-10 \cong \mathrm{C}$ \\
\hline Annual module degradation & $0.5 \%$ \\
\hline Maximum efficiency & $18.6 \%$ \\
\hline
\end{tabular}

The number of modules per array is limited by the maximum DC current for the serial connection of modules and by the maximum authorized inverter input tension. For low temperatures, the module operating pressure increases until reaching the maximum open circuit tension. To avoid inverter damage in winter days, it is necessary to guarantee that the open circuit tension never overtakes the inverter maximum allowable DC tension. The maximum of modules connected in an array $n m a x$ is defined by the rate between the maximum inverter inlet tension and open circuit tension at $-10 \mathrm{oc}^{[19]}$, as defined by the Equations (2) and (3).

$$
n_{\max }=\frac{V_{\max , I N V}}{V_{O C\left(-10^{\circ} \mathrm{C}\right)}}
$$

$V_{O C\left(-10^{\circ} \mathrm{C}\right)}=\left(1-\frac{35^{\circ} \Delta V}{100}\right) V_{O C}$

The minimum number of modules per array is determined by the minimum operation tension of the inverter and the least favorable tension conditions that happen at an operating temperature of 70 o $\mathrm{C}^{[19]}$, again according to the two following equations,

$$
n_{\min }=\frac{V_{\min , I N V}}{V_{M P P\left(70^{\circ} C\right)}}
$$

$V_{M P P\left(70^{\circ} \mathrm{C}\right)}=\left(1+\frac{45^{\circ} \Delta V}{100}\right) V_{M P P}$

The number of parallel rows is limited by the number of the inverter inputs. For the chosen inverter, the PIKO 15 from Kostal Solar Electric ${ }^{[20]}$, this value is 3 . It is also necessary to find out if the PV output current is anytime superior to the maximum limit input current of the inverter, $i$. e., it is necessary to guarantee the limitation imposed by Eqs. $\underline{6}$ and 7 [19]

$$
\begin{aligned}
& N_{\text {rows }, p} \leq \frac{I_{\text {max }, I N V}}{I_{n, r o w}} \\
& I_{\text {rows }, I N V}=\frac{P_{\text {max }, I N V}}{V_{I N V}}
\end{aligned}
$$

The maximum electricity current that crosses each row of modules In, row is the maximum current of the selected module $I s c=9.88 \mathrm{~A}$ at standard temperature conditions (STC). Because this current increases with the module operating temperature, its maximum happens at the maximum authorized temperature value, $70 \circ \mathrm{C}^{[21]}$. The inverters are designed to compensate for the inductive charges and to keep the power factor close to one, and this maximizes the power transfer. For design purposes, the associated power factor was assumed as one ${ }^{[22]}$. Table 2 presents the results of the previous analysis based on the inverter characteristics, also shown in the same table ${ }^{[20]}$.

The adequate choice of the PV modules orientation and inclination is important to maximize the electricity production. The modules faces in the south hemisphere must be turned to the North, and the corresponding solar azimuth angle $\gamma s$ must be $180 \mathrm{o}^{[23]}$, while the panel inclination angle must be equal to the local latitude ${ }^{[24]}$. However, based on studies that were carried out in Angola and African coastal regions it is recommended that such inclination must be $10 \cong$ more than the latitude value in order to facilitate the self-cleaning process of the modules by means of the rain. Thus, in the present study the value adopted for the modules inclination angle $\beta$ was 22 o relatively to the ground surface ${ }^{[25]}$. The variable coastal climate regime in this region of Angola, presents a low to moderate rainfall, as well as moderate winds, 
mainly from September to April during the rainy season and this facilitates the modules cleaning process ${ }^{[8]}$.

Table 2. Obtained results from the inverters analysis.

\begin{tabular}{|c|c|c|c|}
\hline $\begin{array}{c}\text { Inverter } \\
\text { characteristics }\end{array}$ & $\begin{array}{c}\text { Maximum } \\
\text { number of } \\
\text { modules } \\
\text { per row }\end{array}$ & $\begin{array}{l}\text { Minimum } \\
\text { number of } \\
\text { modules } \\
\text { per row }\end{array}$ & $\begin{array}{c}\text { Maximum } \\
\text { number of } \\
\text { parallel } \\
\text { rows }\end{array}$ \\
\hline Vmax,INV $1,000 \mathrm{~V}$ & \multirow{5}{*}{$19(19.2)$} & \multirow{5}{*}{$5(4.7)$} & \multirow{5}{*}{$4(4.05)$} \\
\hline Vmin, INV $160 \mathrm{~V}$ & & & \\
\hline $\operatorname{Voc}(-10 \circ C) 52.1 \mathrm{~V}$ & & & \\
\hline$V M P P(70 \circ C) 44 \mathrm{~V}$ & & & \\
\hline Imax,INV $\quad 40 \mathrm{~A}$ & & & \\
\hline
\end{tabular}

Although there are sun tracking PV modules, the choice was for fixed modules keeping low investment and operating costs. The mobile tracking system includes a certain number of movable components that might be jeopardized by the marine breezes increasing failure risk. Besides, they ought to be connected to an energy source further increasing the energy and financial costs of the whole setup ${ }^{[23]}$. The module support structure must also be carefully accounted for. The structure must guarantee the adequate positioning of the modules as well as their cooling to allow the thermal dissipation of the excess incoming solar heat, to reduce the drop in the modules performance with operating temperature increase. Although the modules will be installed with the above-mentioned $22 \circ$ inclination, the structure must allow modifications in this inclination angle if it is lately found that some small changes could lead to system improvements during some months of the year. Besides this, the structure must be built with corrosion resistant material and be stiff enough to account for its own weight as well as to withstand strong stormy winds ${ }^{[23]}$.

In the Southern hemisphere the winter solstice is on the $21^{\text {st }}$ July and to avoid self-shading phenomena the worst case must be considered, precisely in this solstice day when the solar height is the lowest, provoking a bigger shadow and leading to a strong reduction on the PV generation potential. If on this $21^{\text {st }}$ July, between 10 and $14 \mathrm{~h}$ true solar time (TST), there are now shading effects among the PV modules, then this self-shading phenomenon does not take place for any other day during the year ${ }^{[23]}$.

To determine the minimum distance between two consecutive rows of PV modules, Table 3 presents the results for the solar angles calculated at $10 \mathrm{~h}$ TST at the winter solstice.

Table 3. Solar angles on the $21^{\text {st }}$ July, at $10 \mathrm{~h}$ TST

\begin{tabular}{|l|l|l|l|}
\hline $\begin{array}{c}\text { Solar declination } \\
\delta \boldsymbol{s}\end{array}$ & $\begin{array}{c}\text { Solar hour } \\
\text { angle } \omega\end{array}$ & Solar height $\alpha \boldsymbol{s}$ & Azimuth $\boldsymbol{\gamma s}$ \\
\hline $23.45 \circ$ & $-30 \circ$ & $43.53 \circ$ & $-39.25 \circ$ \\
\hline
\end{tabular}

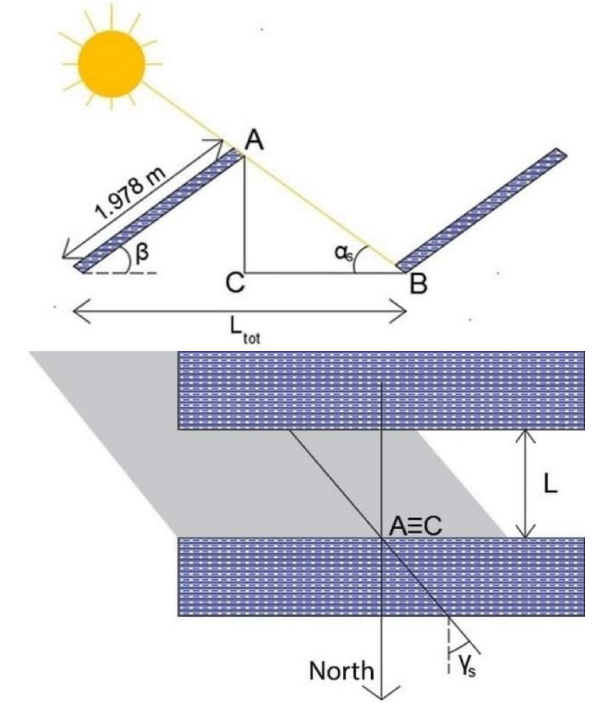

a) Lateral projection

b) Horizontal projection

Figure 5. Scheme for the determination of minimum distance between modules.

Taking into account the geometry shown in Figure 5 , it is possible to calculate the minimum distance between modules $L_{\text {tot }}$ using Eqs. 8 to 10 ,

$\tan \alpha_{s}=\frac{\overline{A C}}{\overline{C B}} \Leftrightarrow \tan 43.53^{\circ}=\frac{1.978 \sin 22^{\circ}}{\overline{C B}} \Leftrightarrow \overline{C B}=0.78[\mathrm{~m}]$

$L=\overline{C B} \cos \gamma_{s}=0.60[\mathrm{~m}]$

$$
L_{t o t}=1.978 \cos 22^{\circ}+0.60=2.43[\mathrm{~m}]
$$

Thus, the minimum distance to avoid self-shading effects is $2.43 \mathrm{~m}$. To account for maintenance procedures, another $1 \mathrm{~m}$ was added to the previous distance, so that a separation of $3.43 \mathrm{~m}$ between two consecutive rows (arrays) of PV modules was adopted. Besides this, a separation of $0.04 \mathrm{~m}$ was used between PV consecutive modules in the same row (array) to avoid any mechanical damage promoted by dilatation phenomena.

The PV plant will then have 2,784 PV modules, corresponding to an installed power of de $1,016.16 \mathrm{kWp}$ as each module has a peak power of $365 \mathrm{~W}$, as shown in Table 1 . As the base area available of this study was of $10,000 \mathrm{~m}^{2}$, the total surface area of the PV modules is of 5,456.64 $\mathrm{m}^{2}$.

The layout of the PV system was carried out in the SketchUp with the Plug- In Skelion extension and in Figure 6 it is shown the solstice instant at $10 \mathrm{~h} \mathrm{TST}{ }^{[26]}$, while Table 4 presents data that allow the calculation of the legal time $(L T)$ at solstice at $10 \mathrm{~h}$ TST. $B$ is a factor on the time equation.

$T E=9.87 \sin (2 B)-7.53 \cos (B)-1.5 \sin (B)$

$$
L T=T S T-\lambda / 15-T E
$$

Table 4. Determination of $L T$ at $10 \mathrm{~h}$ of TST

\begin{tabular}{|c|l|l|c|c|}
\hline $\boldsymbol{B}$ & Time equation $\boldsymbol{T E}$ & Longitude $\boldsymbol{\lambda}$ & $\boldsymbol{T S T}$ & $\boldsymbol{L T}$ \\
\hline$\pi / 2$ & $8.37 \mathrm{~min}$ & $13.25 \circ$ & $10 \mathrm{~h}$ & $8: 58 \mathrm{~h}$ \\
\hline
\end{tabular}




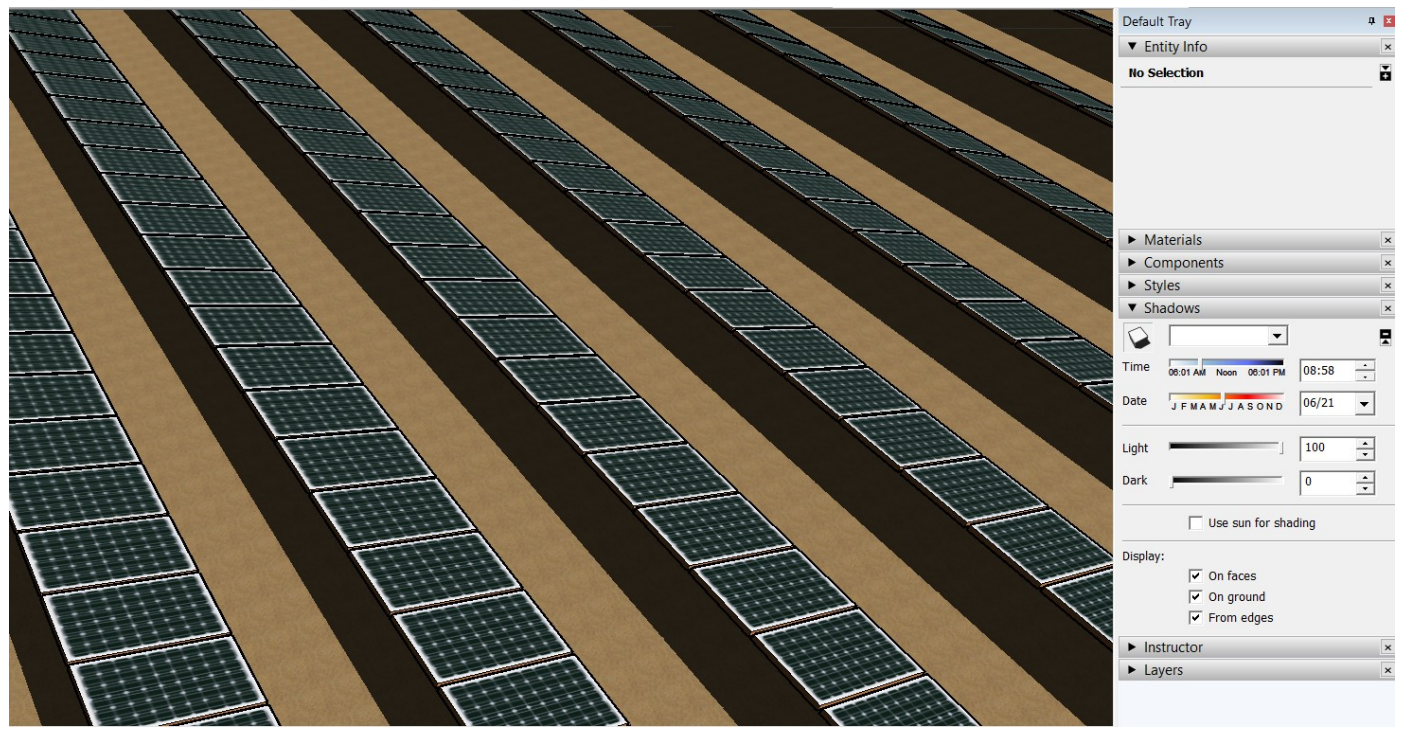

Figure 6. Layout of PV panels in the Sketch Up software at winter solstice at $10 \mathrm{~h}$ TST.

\subsection{Design of the Photovoltaic System in the Polysun Software}

The Polysun software has several capabilities, namely the design, and sizing of thermal or photovoltaic systems; it gives world meteorological data and allows the economic evaluation of solar systems ${ }^{[15]}$. Because the location of the PV plant is by the sea, average values were considered for the natural ventilation, as suggested by the software. The tension in the Angola electricity network is $220 \mathrm{~V} / 380 \mathrm{~V}$ at $50 \mathrm{~Hz}$ frequency, being the inverters responsible to supply the electricity to the mains according to the mentioned values. The final configuration has 58 inverters, with 16 PV modules per row. Each inverter has three entrances leading to a total amount of 2,784 PV modules in the system $58 \times(16+16+16)$.

Considering the energy losses typical values of the region under consideration, as given by PolySun, were adopted, namely:

i. Dirtiness losses, $8.5 \%$. According to some studies carried out in Angola, this value can reach $10 \%$. However, taking into account the modules inclination of more 10 o beyond local latitude it can be assumed that one can propose a 1.5 percentage points of reduction in

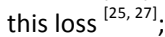

ii. Incompatibility losses, $4 \%$. This is a conservative value considering typical values for this kind of energy loss ${ }^{[28]}$;

iii. Cable losses, $2 \%$. The normal situation is in the 1 to $2 \%$ range, and again a conservative value was taken ${ }^{[29]}$.

\section{Results}

\subsection{Electricity production and $\mathrm{CO}_{2}$ emissions}

The $\mathrm{CO}_{2}$ avoided emissions were calculated by assuming the same amount of electricity produced in a fossil fuel power plant at peak conditions. As there are no known $\mathrm{CO}_{2}$ emission factors for electricity production in Angola, the corresponding value for Portugal, 0.47 $\mathrm{kg}_{\mathrm{CO} 2} / \mathrm{kWh}$, was chosen ${ }^{[30]}$.

Figure 7 presents the monthly $D C$ and the $A C$ production for the months of the year, as well as the $\mathrm{CO}_{2}$ emissions reduction for the PV under study. The difference between the DC (yellow) and the AC (blue) production depends on the inverters efficiency. This efficiency has low fluctuations in the different months as the average temperature has also small annual variations. Maximum avoided $\mathrm{CO}_{2}$ emissions are higher for months with higher production, reaching a peak in May.

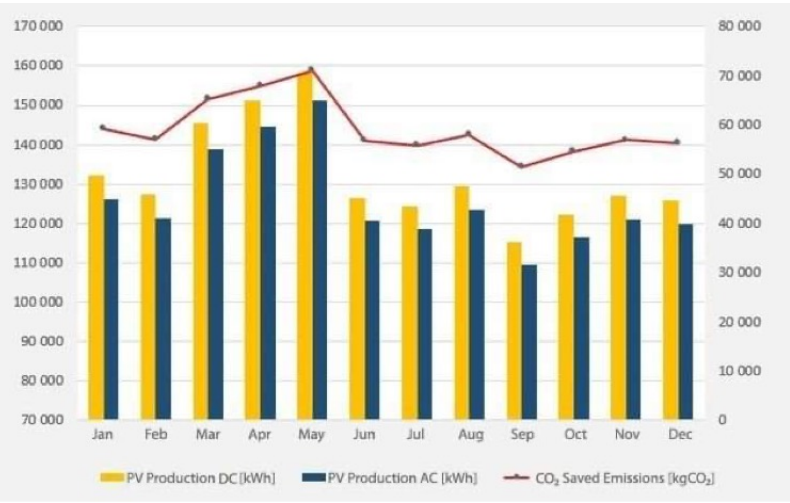

Figure 7. Monthly $\mathrm{DC}$ and $\mathrm{CC}$ electricity production and $\mathrm{CO}_{2}$ emissions economy.

To evaluate the productivity of the PV system two parameters are defined. The first is the specific energy efficiency $Y_{f}$ given by the rate between the annual DC energy production [kWh] and the installed power $[\mathrm{kWp}]^{[31]}$,

$Y_{f}=\frac{E_{D C}}{\dot{W}_{\text {inst }}}$

The performance ratio $P R$ is an important parameter to measure the PV system quality. It evaluates the deviation of the system operating conditions and from the STC conditions as well as external factors interactions, like equipment losses or the temperature influence. It is the ratio between the real $\dot{W}_{A C}$ and the theoretical energy production $\dot{W}_{\text {inst }}\left(\frac{\dot{G}_{T}}{\dot{G}_{T, S T C}}\right)^{[31]}$.

$P R=\frac{\dot{W}_{A C}}{\dot{W}_{\text {inst }}\left(\frac{\dot{G}_{T}}{\dot{G}_{T, S T C}}\right)}$

This PR value is independent from the PV system location. Besides evaluating the energy efficiency and reliability, it also may compare the efficiency of a given system with the efficiency of other systems in different locations. The closer to $100 \%$ is this ratio the better, although 
in the region under consideration the dirtiness losses have a significant importance thus penalizing it.

Table 5 shows the results from the Polysun simulation for the first year of operation of the PV plant. Looking at the results the PV system produces annually about 1,585 MWh DC, and with the conversion losses, the AC yearly production is around $1,512 \mathrm{MWh}$. These inverters have an average high efficiency; their maximum theoretical value is 97.9 $\%{ }^{[20]}$. They operate close to their optimum working condition because the ambient temperatures in the Benguela region rarely reach very high values. The subsequent avoidance of annual $\mathrm{CO}_{2}$ emissions, above the $700 \mathrm{t}$ in this first operational year, and the obtained high specific efficiency are both in accordance with the high PV potential of the region, as shown in Figure 1. The average performance ratio takes a moderate value due to the system location, by the sea. This index is dependent upon the quality of maintenance and cleaning plans as well as components damage forecast ${ }^{[31]}$ and the Polysun takes these factors into account according to the globe region were the plant is installed or to be installed.

Table 5. Performance results of the PV plant for the first year of operation.

\begin{tabular}{|l|l|}
\hline \multicolumn{1}{|c|}{ Parameter } & \multicolumn{1}{c|}{ Value } \\
\hline Incident solar energy & $11,120.55 \mathrm{MWh}$ \\
\hline DC energy production & $1,584.95 \mathrm{MWh}$ \\
\hline AC energy production & $1,511.70 \mathrm{MWh}$ \\
\hline $\mathrm{CO}_{2}$ emissions reduction & $710.47 \mathrm{t}_{\mathrm{cO} 2}$ \\
\hline Average inverter efficiency & $95.3 \%$ \\
\hline Specific efficiency $Y f$ & $1,487.6 \mathrm{kWh} / \mathrm{kWp}$ \\
\hline Average performance ratio $P R$ & $72.8 \%$ \\
\hline
\end{tabular}

\subsection{Energy and Exergy Losses}

The energy losses of a PV system can be quantified and qualified through the energy and the exergy analysis. The energy and exergy efficiencies are thus considered performance indicators and allow the characterization of the losses during the solar radiation process and subsequent conversion into electricity ${ }^{[32]}$. In these analyses, only the DC electricity production is taken into account. The following conversion of $D C$ into $A C$ is only a matter of the inverter performance taking place outsider the PV modules.

The electrical energy produced in the PV system is equal to its exergy, as electricity is only a type of work energy transfer. On the other end, the thermal energy captured by a thermal solar panel depends upon its temperature, and its heat exergy equals the heat energy times the Carnot factor ${ }^{[33,34]}$. In the case of a PV solar panel, the thermal energy available at the panel's surface will not be converted into work and is a thermal energy and exergy loss towards the environment. The energy efficiency of a PV panel $\eta_{e n}$ is the ratio between the electricity generated $\dot{W}_{D C}$ and the total incident solar energy at the panel surface $\dot{G}_{T} A^{\prime}$

$\eta_{e n}=\frac{\dot{W}_{D C}}{\dot{G}_{T} A}$

The exergy efficiency is the ratio between the outlet exergy and the inlet exergy. As already referred, the outlet exergy is equal to the outlet energy $\dot{E} x_{\text {ele }}=\dot{W}_{D C}$, whereas the inlet exergy is the inlet energy $\dot{G}_{T} A$, times an exergy factor as shown in Eq. $16^{[35]}$.

$\dot{E} x_{\text {solar }}=\left[1+\frac{1}{3}\left(\frac{T_{\text {amb }}}{T_{\text {sun }}}\right)^{4}-\frac{4}{3}\left(\frac{T_{a m b}}{T_{\text {sun }}}\right)\right] \dot{G}_{T} A$ where $T_{\text {sun }}$ is the apparent sun temperature, $5777 \mathrm{~K}$ and $T_{a m b}$ is the ambient temperature.

Then, the exergy efficiency $\eta_{e x}$ is given by,

$\eta_{e x}=\frac{\dot{E} x_{e l e}}{\dot{E} x_{\text {solar }}}$

In fact, the output exergy is the summation of the electric exergy with the exergy of the thermal losses. However, as these thermal energy losses escape to the environment its exergy, when reaching the ambient temperature, is zero ${ }^{[33,34]}$. Figure 8 shows the annual evolution of the monthly energy and exergy efficiencies for the year under study.

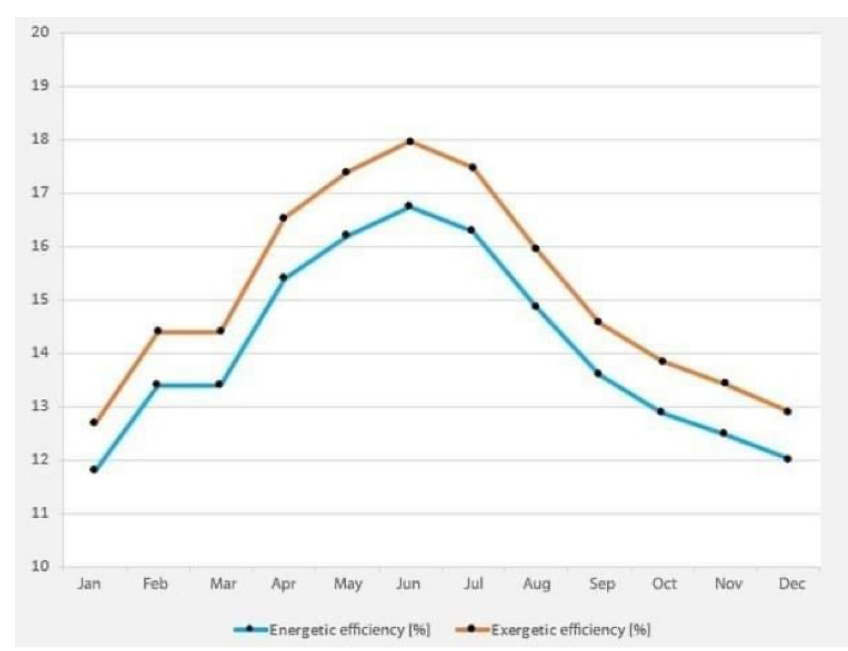

Figure 8. Annual evolution of the energy and exergy efficiency of the PV system.

As expected, for warmer months the energy efficiency is lower as the performance of the solar panels reduces with temperature increase. However, in spite of higher conversion efficiency of the solar cells during the cooler season, the months with higher electricity production are at the end of the warm season, Figure 7, i. e., the higher solar radiation overruns the higher efficiency in the cooler season. The annual average energy efficiency of the PV system is of $14.3 \%$. Although January has the highest global radiation, Figure 7 , the combination of several factors impacting on the electricity production, the energy conversion efficiency is lower in this month, being April and May the leading months in terms of produced electricity.

The exergy efficiency takes values above its energy counterpart. The exergy factor $\left[1+\frac{1}{3}\left(\frac{T_{a m b}}{T_{\text {sun }}}\right)^{4}-\frac{4}{3}\left(\frac{T_{a m b}}{T_{\text {sun }}}\right)\right]$, appearing in the calculation of $\dot{E} x_{\text {solar }}$, in the denominator of Eq. 17, having a value below one, is the responsible for such result. This means that, this solar to electricity conversion technique is exemplary in thermodynamic terms, and the annual average exergy efficiency is of $14.7 \%$.

\section{Conclusions}

The incident solar radiation in Angolan is high and almost constant along the year, and there is a positive convergence of several factors, the high incident solar radiation, the low ambient temperature variation, the low wind velocity in coastal regions and a large availability of free land for the installation of large-scale PV systems. In particular, the Benguela region has all the requirements for the installation of a PV central.

This study on the first year performance of a hypothetical 1-hectare solar PV plant located in the Baía Azul Beach, in Benguela, Angola lead 
to the design of plant composed by 2,784 DuoMax 365 PV modules from Trina Solar Company. The plant performance was evaluated by means of the VelaSolaris Polysum software package. The total surface area of the PV modules was of $5,456.64 \mathrm{~m}^{2}$. The annual DC and AC electricity production was respectively of 1,584.95 $\mathrm{MWh}$ and 1,511.70 $\mathrm{MWh}$ allowing a total of $710.47 \mathrm{t}_{\mathrm{CO} 2}$ of $\mathrm{CO}_{2}$ emissions reduction and a performance ratio of $72.8 \%$. The chosen inverters, PIKO 15 from Kostal Solar Electric, had an average efficiency of $95.3 \%$. The annual evolution of the energy and exergy efficiency of the PV system calculated and the average energy and exergy efficiencies of the PV system were respectively of $14.3 \%$ and $14.7 \%$.

\section{Acknowledgment}

The authors are grateful by the INEGI support to carry on this study.

\section{Conflict of interest}

The authors declare that there is no conflict of interest regarding the publication of this manuscript.

\section{References}

[1] REN (2019). Renewables 2019 Global Status Report. Athens, Greece.

[2] Nkwettal, D. N.; Smyth, M.; Van Thong, V.; Driesen, J. and Belmans, R. (2010). Electricity supply, irregularities, and the prospect for solar energy and energy sustainability in Sub-Saharan Africa. Renewable and Sustainable Energy, 2, 023102.

[3] Sampaio, P. G. V. and González, M. O. A. (2017). Photovoltaic solar energy: Conceptual framework. Renewable and Sustainable Energy Reviews, 74, 590-601.

[4] Dombaxe, M. I. M. (2011). Os Problemas Energéticos em Angola: Energias Renováveis, a Opção Inadiável (The Energy Problems in Angola: Renewable Energy, the Unavoidable Option). Master Dissertation. Faculdade de Ciências Sociais e Humanas da Universidade Nova de Lisboa. Lisboa, Portugal.

[5] Mas'ud, A. A.; Wirba, A. V.; Muhammad-Sukki, F.; Albarracín, R.; AbuBakar, S. H.; Munir, A. B. and Bani, N. A. (2016). A review on the recent progress made on solar photovoltaic in selected countries of sub-Saharan Africa. Renewable and Sustainable Energy Reviews, 62, 441-452.

[6] MINEA. (2017). Angola Energia 2025 (Angola Energy 2025). República de Angola - Ministério da Energia e Águas. Luanda, Angola.

[7] Cristóvão, S. (2011). Fontes de Energia Renováveis no Contexto Angolano (Renewable Energy Sources in the Angolan Context) https://www.yumpu.com/pt/document/read/34635608/fontes-deenergia-renovaveis-no-contexto-angolano-seminario. Apresentação da Diretora Nacional das Energias Renováveis. Luanda, Angola. Accessed on March 2020.

[8] CESO. (2012). Estudo de Mercado sobre Província de Benguela (Market Study of the Benguela Province). CESO Development Consultants. Lisboa, Portugal.

[9] Tyilianga, J. F. (2017). Problemática do abastecimento de água e saneamento de águas residuais no município de Lubango/Angola (The problematics of water distribution and wastewater sanitation on the Lubango/Angola municipality). Master Dissertation. Faculdade de Ciências Sociais e Humanas da Universidade Nova de Lisboa. Lisboa, Portugal.

[10] Brunet, C.; Savadogo, O.; Baptiste, P. and Bouchard, M. (2018). Shedding some light on photovoltaic solar energy in Africa - A literature review. Renewable and Sustainable Energy Reviews, 96, 325-342.

[11] SolarGIS. (2020). Solar resource maps and GIS data for 200+ countries. (https:// solargis.com/maps-and-gis-data/overview). Accessed on March 2020.

[12] Ramos, L. F. (2020). Análise do Desempenho de um Sistema Solar Fotovoltaico na Região de Benguela (Analysis of the Performance of a Solar Photovoltaic System in the Benguela Region). Master
Dissertation on Mechanical Engineering. Faculdade de Engenharia da Universidade do Porto. Porto, Portugal.

[13] Costa, S. C. (2019). Análise do desempenho térmico de uma piscina solar na região de Benguela, Angola (Analysis of the thermal performance of a solar pond in the Benguela region, Angola). Master Dissertation on Mechanical Engineering. Faculdade de Engenharia da Universidade do Porto. Porto, Portugal.

[14] Google Maps. (2020). https://www.google.pt/maps. Accessed on March 2020.

[15] VelaSolaris. (2020). PolySun Software version 11.2.8.27 https://www.velasolaris.com/wpcontent/uploads/2019/02/Tutorial_EN.pdf.

[16] Ascencio-Vásquez, J.; Brecl, K. and Topič, M. (2019). Methodology of Köppen-Geiger-Photovoltaic climate classification and implications to worldwide mapping of PV system performance. Solar Energy, 191, 672-685.

[17] Chen, C. J. (2011). Physics of Solar Energy. John Wiley Sons, Inc. New Jersey, USA.

[18] Castro, R. (2011). Uma introdução às energias renováveis: eólica, fotovoltaica e mini- hídrica (An introduction to the renewable energies: eolic, photovoltaic and mini-hydric). Instituto Superior Técnico. Lisboa, Portugal.

[18] Trina Solar. (2020). Trina Solar Products. (https://www.trinasolar.com/en-glb/product). Accessed on March 2020.

[20] Kostal. (2020). Smart connections. Datasheet Piko 15 https://krannich-

solar.com/fileadmin/content/data_sheets/inverter/en/Datenblatt PIKO_15_EN.pdf. Accessed on March 2020.

[21] Chumpolrat, K.; Sangsuwan, V.; Udomdachanut, N.; Kittisontirak, S. Songtrai, S.; Chinnavornrungsee, P.; Limmanee, A.; Sritharathikhun, J. and Sriprapha, K. (2014). Effect of Ambient Temperature on Performance of Grid-Connected Inverter Installed in Thailand. International Journal of Photoenergy, 2014, ID 502628.

[22] Islam, M.; Mekhilef, S. and Hasan, M. (2015). Single phase transformerless inverter topologies for grid-tied photovoltaic system: A review. Renewable and Sustainable Energy Reviews, 45, 69-86.

[23] Galdino, M. and Pinho, J. (2014). Manual de Engenharia para Sistemas Fotovoltaicos (Engineering Handbook for Photovoltaic Systems). CEPEL-CRESESB. Rio de Janeiro, Brasil.

[24] Mcvoy, A.; Markvart, Y. and Castaner, L. (2012). Practical Handbook of Photovoltaics- Fundamentals and Applications. Elsevier. Oxford, England.

[25] Jacobson, M. Z. and Jadhav, V. (2018). World estimates of PV optimal tilt angles and ratios of sunlight incident upon tilted and tracked PV panels relative to horizontal panels. Solar Energy, 169 55-66.

[26] Trimble. (2017). SketchUp Make 2017 User. https://www.bgsu.edu/content/dam/BGSU/libraries/documents/co llab-lab/Sketchup-Tutorial.pdf.

[27] Ghazi, S.; Sayigh, A. and Ip, K. (2014). Dust effect on flat surfaces- A review paper. Renewable and Sustainable Energy Reviews, 33, 742751.

[28] Spertino, F.; Ciocia, A.; Di Leo, P.; Tommasini, R.; Berardone, I.; Corrado, M.; Infuso, A. and Paggi, M. (2015). A power and energy procedure in operating photovoltaic systems to quantify the losses according to the causes. Solar Energy, 118, 313-326.

[29] Ekici, S. and Kopru, M. A. (2017). Investigation of PV System Cable Losses. International Journal of Renewable Energy Research, 7 (2) 807-815.

[30] Pinho, C. (2019). Gestão de Energia Térmica (Thermal Energy Management). Faculdade de Engenharia da Universidade do Porto. Porto, Portugal.

[31] Palmero, A.; Matos, J. and Oliveira, A. (2015). Comparison of software prediction and measured performance of a grid- 
connected. Journal of Renewable and Sustainable Energy, 7, 063102.

[32] Pandey, A. K.; Tyagi, V. V. and Tyagi, S. K. (2013). Exergetic analysis and parametric study of multi-crystalline solar photovoltaic system at a tropical zone. Clean Techn Environ Policy, 15, 333-342.

[33] Kotas T. J. (1985). The exergy method of thermal plant analysis. Butterworth-Heinemann. Tiptree, United Kingdom.
[34] Dincer, I. and Cengel, Y. A. (2001). Energy, Entropy and Exergy Concepts and Their Roles in Thermal Engineering. Entropy, 3(3), 116-149.

[35] Joshi, A. S.; Dincer, I. and Reddy, B. V. (2009). Performance analysis of photovoltaic systems: A review. Renewable and Sustainable Energy Reviews, 13, 1884-1897. 